\title{
Correction to: Climate change and its impacts in the Balearic Islands: a guide for policy design in Mediterranean regions
}

\author{
Cati Torres ${ }^{1} \cdot$ Gabriel Jordà $^{2} \cdot$ Pau de Vílchez ${ }^{3} \cdot$ Raquel Vaquer-Sunyer $^{4} \cdot$ Juan Rita $^{5} \cdot$ Vincent Canals $^{6}$. \\ Antoni Cladera ${ }^{7} \cdot$ José M. Escalona ${ }^{8} \cdot$ Miguel Ángel Miranda $^{9}$
}

Published online: 25 November 2021

(c) Springer-Verlag GmbH Germany, part of Springer Nature 2021

\section{Correction to: Regional Environmental Change (2021) 21: 107 https://doi.org/10.1007/s10113-021-01810-1}

In this article the title was incorrectly given as "Climate change and their impacts in the Balearic Islands: a guide for policy design in Mediterranean regions" but should have been "Climate change and its impacts in the Balearic Islands: a guide for policy design in Mediterranean regions".

The original article has been corrected.

Publisher's Note Springer Nature remains neutral with regard to jurisdictional claims in published maps and institutional affiliations.

The original article can be found online at https://doi.org/10.1007/ s10113-021-01810-1.

Cati Torres

cati.torres@uib.cat

Gabriel Jordà

gabriel.jorda@ieo.es

Pau de Vílchez

pau.devilchez@uib.eu

Raquel Vaquer-Sunyer

raquel.vaquer@marilles.org

Juan Rita

jrita@uib.es

Vincent Canals

v.canals@uib.es

Antoni Cladera

antoni.cladera@uib.es

José M. Escalona

jose.escalona@uib.es

Miguel Ángel Miranda

ma.miranda@uib.es
1 Applied Economics Department and Interdisciplinary Lab On Climate Change (LINCC UIB), Universitat de les Illes Balears, Cra. Valldemossa, km. 7,5, 07122 Palma, Illes Balears, Spain

2 Spanish Institute of Oceanography and Interdisciplinary, Lab On Climate Change (LINCC UIB), Palma, Illes Balears, Spain

3 International Law Department and Interdisciplinary, Lab On Climate Change (LINCC UIB), Universitat de les Illes Balears, Palma, Illes Balears, Spain

4 Fundación Marilles, Palma, Illes Balears, Spain

5 Botanic Lab, Department of Biology and Interdisciplinary, Lab On Climate Change (LINCC UIB), Universitat de les Illes Balears, Palma, Illes Balears, Spain

6 Mechanical Engineering, Industrial Engineering and Construction Department and Interdisciplinary Lab On Climate Change (LINCC UIB), Universitat de les Illes Balears, Palma, Illes Balears, Spain

7 Industrial Engineering and Construction Department and Interdisciplinary Lab On Climate Change (LINCC UIB), Universitat de les Illes Balears, Palma, Illes Balears, Spain

8 Agro-Environmental and Water Economics Institute (INAGEA UIB) and Interdisciplinary Lab On Climate Change (LINCC UIB), Universitat de les Illes Balears, Palma, Illes Balears, Spain

9 Applied Zoology and Animal Conservation Research Group and Interdisciplinary Lab On Climate Change (LINCC UIB), Universitat de les Illes Balears, Palma, Illes Balears, Spain 